\title{
Encouraging Public Transport Use to Reduce Traffic Congestion in Uttara, Dhaka
}

\author{
Abir ATM*, Mostafizur Rahman MD, Farjana Islam and Sirajul Islam \\ Department of Civil and Environmental Engineering (DCEE), North South University, Bangladesh
}

Submission: April 19, 2018; Published: May 30, 2018

*Corresponding author: Abir ATM, Department of Civil and Environmental Engineering (DCEE), North South University, Plot \# 15, Block \# B, Dhaka - 1229, Bangladesh, Email: abirjuly17@hotmail.com

\begin{abstract}
Traffic congestion is one of the most important problems of Dhaka city, the capital of Bangladesh. Many solutions are being worked out to reduce the existing traffic congestion, but most of the solutions failed leading to the increase in traffic congestion day by day. This paper deals with the traffic congestion and its solution at Uttara, one of the prime areas of Dhaka city. Uttara is a northern Thana and a suburb of Dhaka. Public transportation system has been given the most importance in the solution to the traffic congestion in this area, as this sector has been neglected by everyone and its potential has not been used properly yet. Uttara is a very important area of the Dhaka city as it includes the Shahjalal International Airport, Airport Railway Station, and the largest highway which is Dhaka-Mymensigh highway. Therefore traffic congestion at Uttara is leading to time and economical loss. Survey of 200 bus passengers and 200 private car owners in this area were conducted in order to find out where the problem lies in the public transportation sector and what needs to be done to make it user friendly. When asked about the satisfaction level regarding the behavior of the bus staffs , majority with $78 \%$ of them being dissatisfied with their behavior, while only $22 \%$ said that they are satisfied with the behave. When asked if they like to pay an extra bit of fare for better bus service, most of the respondents with $92 \%$ of them agreeing to pay extra bit of fare for good bus service. When the private car owner respondents were asked about why they didn't use public bus, $56 \%$ said due to poor service they didn't use the public bus. A good reliable, comfortable, and safe bus service system should be provided to the people of Uttara. Without providing them a good bus service we can't encourage them to travel in public buses leaving behind their private cars. We tend to think for high solutions which would cost us lots of money but would give us temporary solution. Therefore we tend to ignore these basic and simple solutions which are very easy to impose and are permanent solution. This paper's main motive was to highlight solutions which are being ignored and not given much importance. But the result of the research proved that these simple solutions will result in a huge change in the traffic congestion scenario at Uttara, if it is amplified properly.
\end{abstract}

Keywords: Uttara; Traffic; Sustainable; Management; Public Transport.

\section{Introduction}

Dhaka is one of the biggest and quickest developing urban areas of the world. Its metropolitan populace has developed exponentially to around 18 million today. Dhaka has likewise moved toward becoming the world's most swarmed huge city, with twofold or treble the populace thickness of other world urban communities for example, Tokyo, London and Shanghai. Traffic Congestion is one of the results of the huge population of Dhaka. In spite of the development of a few flyovers, enabling individuals to stop their vehicles on assigned boulevards and transport stops, and stern activity against wrong-side driving, movement blockage in Dhaka keeps on exasperating, making genuine sufferings city suburbanites. A current World Bank study demonstrates that Dhaka's normal movement speed has dropped from $21 \mathrm{~km} / \mathrm{h}$ to $7 \mathrm{~km} / \mathrm{h}$ over the most recent 10 years, marginally over the normal strolling speed. Movement gridlock eats up 3.2 million work hours for every day. Another

examination led by the Copenhagen Consensus Center says that the speed in Dhaka is presently $6.4 \mathrm{~km} / \mathrm{h}$, and that if vehicle development proceeds at its present pace, without significant public transport the normal speed may tumble to $4.7 \mathrm{~km} / \mathrm{h}$ by 2035. Even though Dhaka represents only $1 \%$ of the country's total area, it contributes over $36 \%$ to the GDP and creates $44 \%$ of the country's total employment. The lack of importance given to the public transportation is one of the major reason why public avoids travelling in buses resulting in too much private vehicles in the city causing heavy traffic jam .This research is important because the reasons behind the inhibitions towards the public transportation was needed to be found so that we could reach to solution to this problem and help in decreasing the traffic congestion in the city, especially Uttara area. Uttara area is one of the prime areas of the Dhaka city as it includes the Shahjalal International Airport, Airport Railway station and various 


\section{Civil Engineering Research Journal}

important commercial arena. This area therefore needs to be free from the heavy traffic congestion so that public movement becomes easier here. Hence, we conducted our research in Uttara area of Dhaka city.

\section{Background and Rationale}

Uttara is one of the main areas of the northern Dhaka city. It is bounded by Turag thana and Gazipur Sadar Upazila on the north, Bimanbandar and Pallabi than as on the south, Dakshinkhan thana on the east, Pallabi and Turag thanas on the west. Uttara is arranged by RAJUK and separated into 14 sectors, beginning from sector 1 to sector 19. At the 2011 Bangladesh enumeration, Uttara had a populace of 179,907 . According to the Dhaka Statistical Metropolitan Area figures, male were $56.3 \%$ of the populace and females $43.7 \%$, and around $60 \%$ of the Uttara's populace are grown-ups. Uttara has a normal proficiency rate of $80.2 \%$ (7+ years). Most of the people here are service holders. Uttara area includes the Shahjalal International Airport, Airport Railway station, Dhaka-Mymensingh highway and other important residential and commercial complexes. These important places makes Uttara an area with heavy inflow and outflow of people throughout the day. The heavy traffic congestion in this area is one of the vital problems the people living and travelling in or by Uttara are facing on regular basis. The huge number of private vehicles running in this area and inadequate bus service system is resulting in this heavy traffic congestion The study area for this research were three main points of Uttara where traffic congestion is huge, which are Jasimuddin traffic signal, Airport traffic signal and House building traffic signal. Being such an important area of the Dhaka city where inflow and outflow of people to and from the city is continuous, the transport facilities provided to the people is very poor. The public transport system not used at all effectively. The increased usage of private car in the roads is causing unnecessary traffic in these important streets. There are many suggestions and solutions for the traffic problem in this area by building new roads, flyovers, $u$ loops, metro rail, BRTA system etc. but what we are ignoring is that these are short term traffic solution for this city. These projects will not be a permanent solution to the ongoing traffic problems, in fact the construction and implementation period of this projects will even increase the traffic congestion much more. What we should focus on is permanent solution this traffic problem. An area which consists the airport, railway station, highway road should be kept traffic free or else this would be a huge problem for the people travelling. Public transportation such as public buses are the basic transportation system for the citizens. Unless the public transportation system is fully utilized effectively, we cannot solve the traffic problems no matter how many flyovers, u loop, metro rail, BRTA system we do for the area. Hence, this research was initiated in an attempt to identify the problems in the public transportation sector due to which public is not using this medium of transport and to identify their requirements regarding a public friendly transportation system which would encourage them to travel in buses leaving behind their private vehicles. Providing their desirable transport system would result in less traffic congestion in this area, as the roads would not be covered with huge number private vehicles anymore (Figure 1).

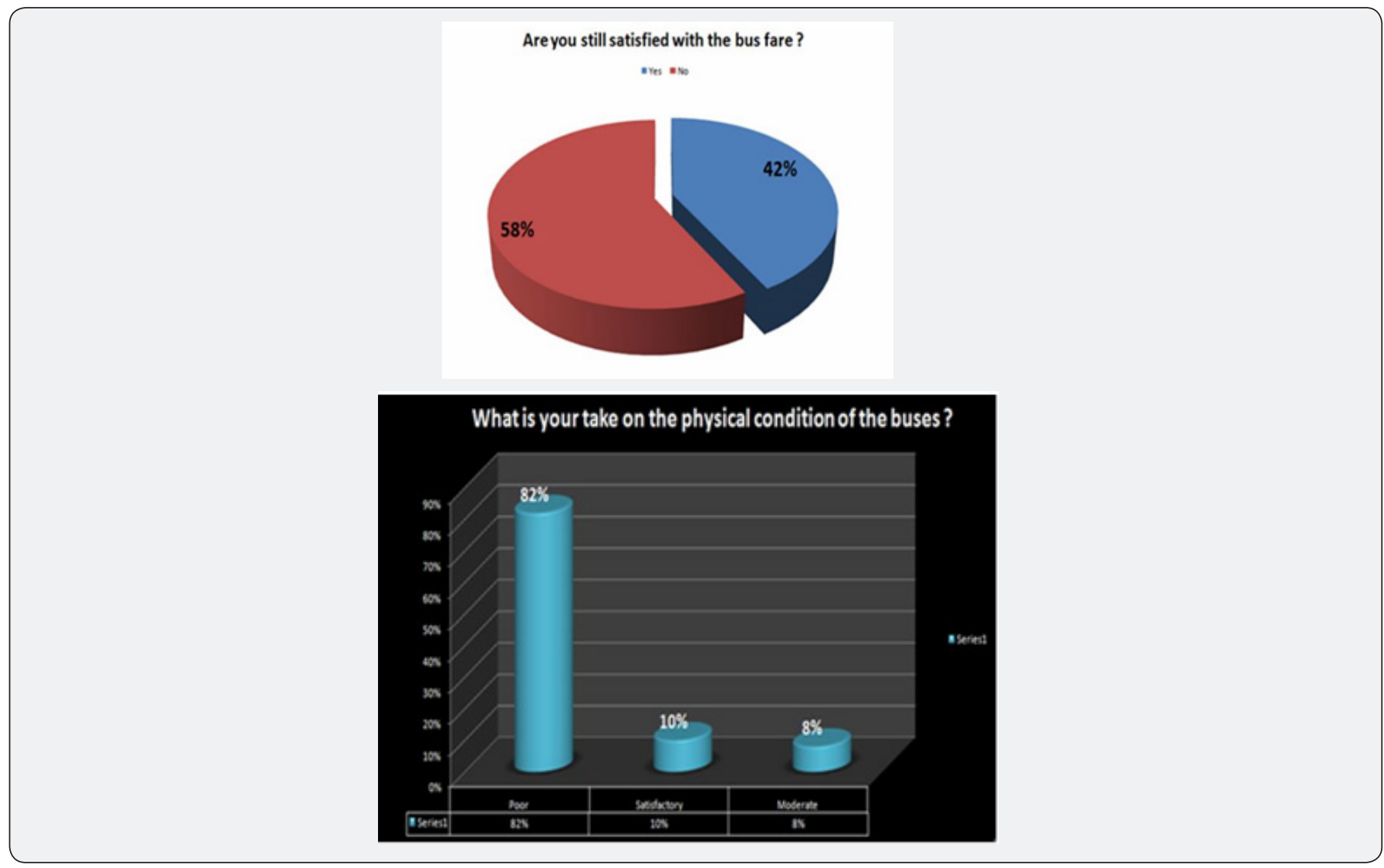




\section{Civil Engineering Research Journal}
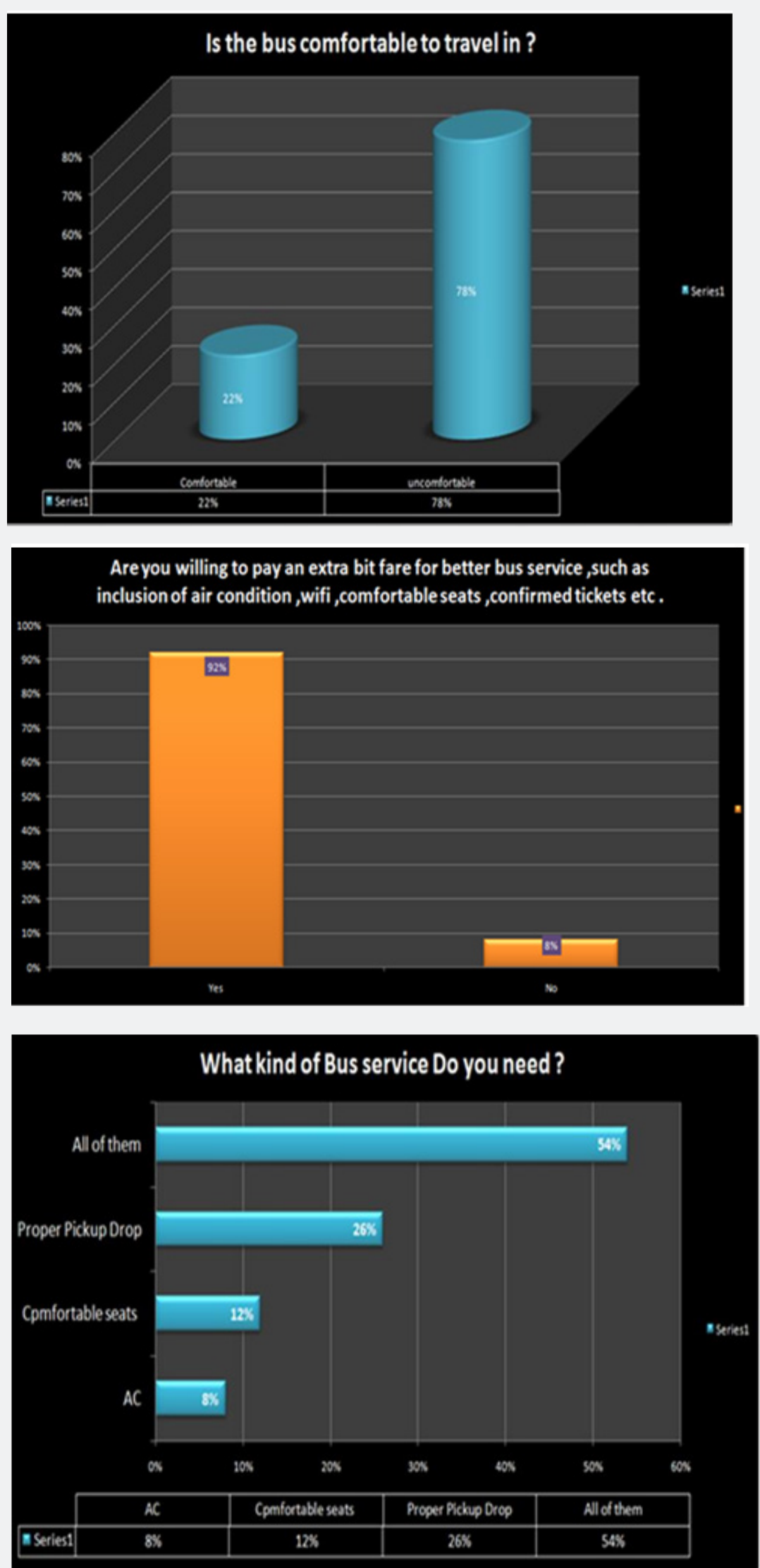


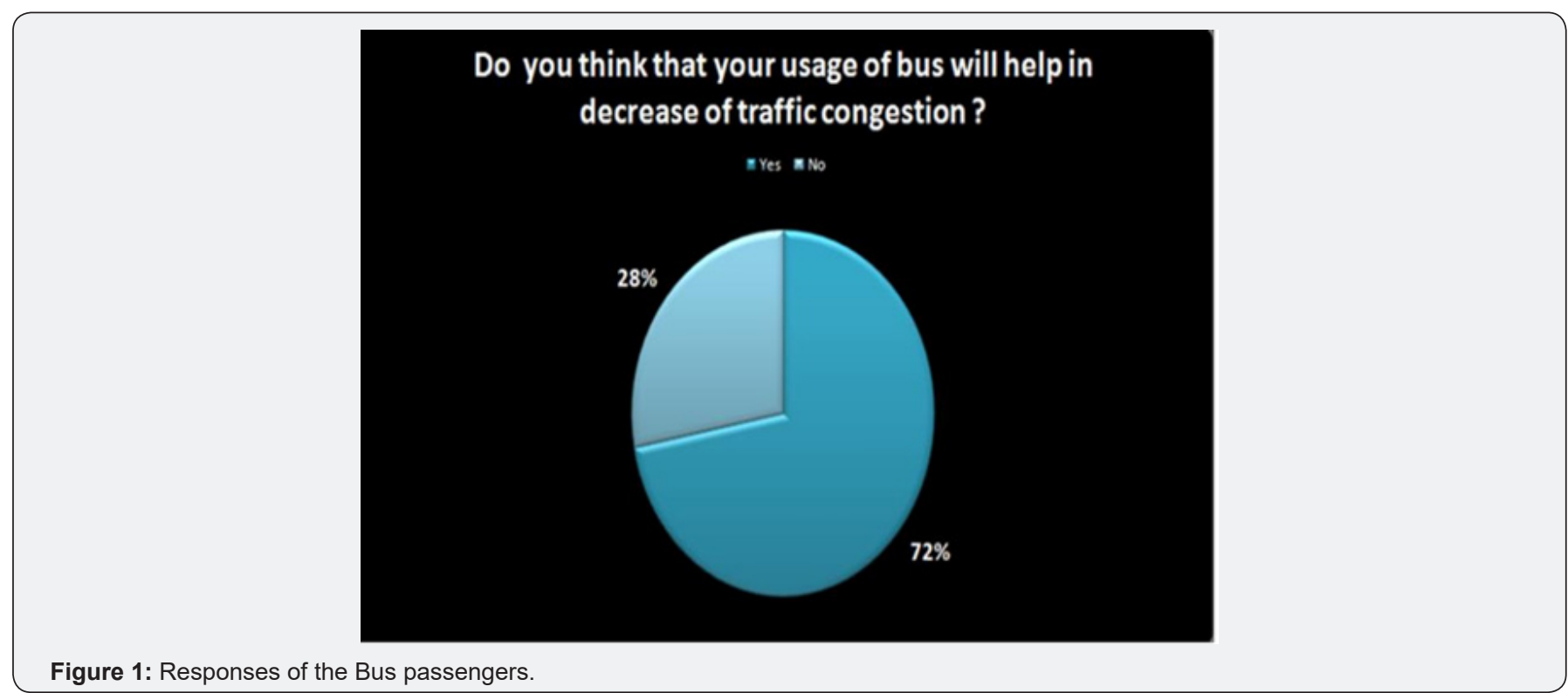

\section{Literature Review}

A few investigations have shown that diverse factors as well as different embraced public transport agreeable approaches have huge effect to advance transit ridership. Public transportation is an entryway to reasonable openness framework. Aside from that, a productive public transportation administrations upgrade individual monetary openings, spare fuel, give monetary openings, spare cash and lessens the natural effects.

Arrangements of conveniences for protect, comfort (i.e. seating courses of action), and security are required at stops where travelers need to pause [1]; consequently the stops or stations are imperative for open transport benefit. Next to the physical requests, booking, running and supervisions of vehicles, toll gathering, and upkeep are the way to administration of open transport. Vuchie distinguished the essential components of execution are: benefit recurrence, working velocity, unwavering quality, wellbeing, line limit (the most extreme number of seats/spaces or people can convey past point along the line amid 60 minutes), beneficial limit, efficiency, and usage. There are a scope of issues influencing open transport tasks; of which dependability, traveler comfort and security is essential. Obviously, the variables may shift in various financial condition with having distinctive open transport frameworks. Trent Busses, transport administrator in Midlands of UK, distinguished clients' best necessities are: dependability/recurrence of administrations, cordiality of administrations, clean transport insides, comfort, esteem for cash, clean transport outsides, simple access, sensible tolls and simple to comprehend, and simple to recollect the timetables [2].

Then again, Tyrinopoulos and Antoniou found that exchange quality and quality benefit are the best need in transport administrations for the clients in Athens. As indicated by them, the key fulfillment markers were the administration recurrence, exchange remove, ticketing framework, and vehicle neatness. Paulley et al. investigated that the trade between modes is one of the critical characteristics of administration quality for open transport in UK; for example strolling and pausing times required at a trade punish the traveler by what might as well be called 21 minute in-vehicle time (IVT) on a transport trip or 37 minute IVT on a prepare trip.

Above data about the level of transport administration of open transport quality depend on the urban areas in Global North, which may not fit for Dhaka City where no timetable is trailed by the transport administrators and both the inside and outside of transport is regularly extremely messy. Truth be told, there are very little look into papers or distributed reports accessible on benefit nature of transport or open transport of the urban communities of Global South is on the grounds that, most likely, the urban areas in South are confronting more issue indeed, even to give supply of open transports to take care of up the demand and henceforth no endeavors/resources for enhanced quality. The vast majority of the investigations on benefit level of transport or open transport managed operational execution pointers [3-5] as opposed to investigating the travelers' conclusion about the nature of ride. From the confirmation of some creating urban communities, Sohail and Maunder contend for guaranteeing sheltered and secure transport stops with arrangement of safe house for travelers and assigned territories for merchants.

\section{Existing Bus Services in Dhaka City}

Transport administrations accessible in Dhaka city could be ordered in two gatherings: counter transport benefit and neighborhood transport benefit. Counter transport benefit has determined stoppages for boarding and landing of travelers and the tickets are sold at the counter of those stoppages. For such 


\section{Civil Engineering Research Journal}

transports, travelers need to buy their tickets from the transport counters just before loading up into transport. A little number of counter transports are aerated and cooled. Conversely, neighborhood transport benefit has no predefined stoppage (stop anyplace in transit for boarding and landing travelers) and travelers pay the reasonable for the transport conductor on transport (in the wake of boarding). Transports of the two kinds frequently remain vigorously packed; generally in light of a hole amongst request and supply. In any case, there are a couple seating administration transports working in certain constrained courses which permit boarding travelers just if there is a vacant seat accessible for the individual. These transports likewise boarding and landing travelers at the predefined stops (at times enable travelers to land at wherever where the travelers need to), and the travelers need to pay for their tickets inside the transport. Just 6 situates in each transport have been saved for the female travelers yet nothing such for handicapped individuals or senior nationals [6].

\section{Methodology}

It was very difficult to cover the entire Uttara region or all the transport courses and administrators of the city because of time and asset limitations. Henceforth, just the 3 noteworthy transport courses, specifically Uttara-Jatrabari course, UttaraMotijheel course, Uttara-Mirpur course had been decided for this examination. While choosing the transport courses it was viewed as that they cover a large portion of the travelers from a to Uttara zone (i.e. the focal territory and the fringe, the arranged and spontaneous region, and the higher-salary and lower-pay private areas). All the real transport specialist co-ops working in the chose course (specified prior) were considered for this examination. While choosing the transport suppliers of a particular course, both the counter administration (and seating administration) and neighborhood benefit was considered to have the entire picture of existing transport administrations of the city [7] (Table 1).

A dialog with the transport administrators (i.e. worker at the counters, transport conductors, transport drivers) was done to know their recurrence of administrations and in addition different issues identified with benefit. A sum of 150 transport travelers (50 from each course) were arbitrarily chosen and met with a foreordained organized poll at various transport stoppages. The poll secured the focuses to investigate their experience and fulfillment level of this present transport travel, and their general assumptions about transport administrations. While choosing the respondents for a specific transport course, it was additionally viewed as that the travelers of all the distinctive transport administrations (administrators), which have been decided for this investigation as appeared in (Table 1), of that course speaks to similarly and the test are drawn from various stoppages of that course. The meetings of transport travelers were directed in ordinary bright week-days in October 2017 for the primary stage and after that again in November 2017 for the second stage; and the overview time was in the vicinity of 08:00 and 18:00 hours of the day. While leading the traveler interviews, once in a while the questioner likewise went on transport alongside the respondents (when the meeting was in the midway however the traveler is boarding into transport as it landed in stoppage) to finish the meeting [8-11].

Table 1: Selected bus route and the operators for interviewing passengers.

\begin{tabular}{|c|c|c|c|}
\hline $\begin{array}{l}\text { Bus Routes } \\
\text { (selected } \\
\text { for this } \\
\text { research) }\end{array}$ & $\begin{array}{l}\text { Bus stops } \\
\text { (passenger } \\
\text { interviews } \\
\text { conducted) }\end{array}$ & $\begin{array}{c}\text { Selected } \\
\text { bus service } \\
\text { (passenger } \\
\text { interviews } \\
\text { conducted) }\end{array}$ & $\begin{array}{c}\text { Types of } \\
\text { the Service }\end{array}$ \\
\hline $\begin{array}{l}\text { Uttara - } \\
\text { Jatrabari }\end{array}$ & $\begin{array}{l}\text { Airport, House } \\
\text { building, } \\
\text { Jasimuddin }\end{array}$ & $\begin{array}{c}\text { - Shuprovat } \\
\text { Paribahan } \\
\text { - Turag Paribahan } \\
\text { - Raida Paribahan }\end{array}$ & $\begin{array}{l}\text { - Local } \\
\text { - Local } \\
\text { - Counter }\end{array}$ \\
\hline $\begin{array}{l}\text { Uttara - } \\
\text { Motijheel }\end{array}$ & $\begin{array}{l}\text { Airport, House } \\
\text { building, } \\
\text { Jasimuddin }\end{array}$ & BRTC & $\begin{array}{c}\text { Air- } \\
\text { conditioned }\end{array}$ \\
\hline \multirow[t]{2}{*}{$\begin{array}{l}\text { Uttara - } \\
\text { Mirpur }\end{array}$} & $\begin{array}{l}\text { Airport, House } \\
\text { building, } \\
\text { Jasimuddin }\end{array}$ & $\begin{array}{l}\text { Projapoti } \\
\text { Paribahan }\end{array}$ & $\begin{array}{l}\text { - Local } \\
\text { - Local }\end{array}$ \\
\hline & & $\begin{array}{l}\text { Jabalenur } \\
\text { Paribahan }\end{array}$ & \\
\hline
\end{tabular}

\section{Results and Discussion}

The results from the questionnaire concluded that the passengers are not happy with the bus service system, they want a more reliable, comfortable bus service system in the area so that they can travel better. $52 \%$ my respondents travel in bus regularly, whereas $20 \%$ of the respondents don't travel in bus regularly. $20 \%$ of respondents travel in bus sometimes and only $8 \%$ of the respondents travel often. $68 \%$ of my respondents said they find seats available while travelling while $32 \%$ of them said they find the bus over crowded while travelling when they were asked about it. When asked about their opinion on the physical condition of the buses, majority of them with $82 \%$ said that they think the condition of the buses are poor whereas only 10 percent think its satisfactory and $8 \%$ thinks its moderate. When asked about the satisfaction level regarding the behavior of the bus staffs, majority with $78 \%$ of them being dissatisfied with their behavior, while only $22 \%$ said that they are satisfied with the behave. When asked if they like to pay an extra bit of fare for better bus service, most of the respondents with $92 \%$ of them agreeing to pay extra bit of fare for good bus service whereas $8 \%$ of them are not willing to pay extra bit of fare for better bus service. When asked about how much extra fare they want pay for better bus service, $52 \%$ said they would like to pay 7-10 Tk for better bus service followed by $22 \%$ with $2-5 \mathrm{Tk}, 14 \%$ with $57 \mathrm{Tk}$ and only $12 \%$ with $0-2 \mathrm{Tk}$. When asked if they have any intention to buy private car in future, $64 \%$ of them said they have intention to buy private car in future where $36 \%$ said they don't have any intention of buying private car in future. When asked why they intend to buy private car in future, majority of them with $54 \%$ said for more comfort than bus, followed by $26 \%$ 


\section{Civil Engineering Research Journal}

saying for privacy, $16 \%$ due to poor bus service and merely $4 \%$ as personal luxury [12].

\section{Recommendation}

A good reliable, comfortable, and safe bus service system should be provided to the people of Uttara. Without providing them a good bus service we can't encourage them to travel in public buses leaving behind their private cars. The north city corporation of Dhaka should subsidize the public transport sector more so that bus owners can provide good service in reasonable fare. Color coded buses can be used so that people who are not educated enough can easily know which route the bus is travelling to. There are no bus bays in Uttara. Bus bays especially in House building, Jasimuddin and Airport area is required. The buses load and unload the passengers in the middle of the road which is very unsafe for the passengers, this also blocks the middle of the roads causing traffic congestion. Bus bays will ensure safe loading and unloading of passengers and no unnecessary congestion in the middle of the road due to this. More double decker buses in this route will be a good option as it will allow one bus to carry a lot of passengers rather than minibuses. Schools, offices, commercial institutes etc should have their own bus service so that one bus can carry their people rather than individuals coming in cars, other transport medium causing traffic jam. Car pool or car sharing can be a good option in Uttara area as there are high amount of car users in this area. People travelling in same destination can travel in one car sharing rather than travelling in multiple cars causing traffic congestion. A law can be enforced of not using private cars during specific time intervals of the day especially in the peak hours of morning and evening which can reduce the traffic congestion marginally [13-16].

\section{Conclusion}

Uttara is an area which is very important and busy area of Dhaka city. Keeping this area traffic free is necessary as the airport, railway station is in this area. People coming from abroad will have a very negative point of view regarding our country when they see unbearable traffic jam in this area. This is the first area they see when they visit Bangladesh .That's why is necessary for us to keep this area traffic free. The suggestions provided are very basic suggestions which we always ignore. We tend to think for high solutions which would cost us lots of money but would give us temporary solution.Therefore we tend to ignore these basic and simple solutions which are very easy to impose and are permanent solution. This papers main motive was to highlight this solutions which are being ignored and not given much importance. But the result of the research proved that these simple solutions will result in a huge change if it is amplified properly. No matter how many new things you construct to decrease traffic jam, unless the public transport sector is utilized, it's of no use.

\section{References}

1. Currie GV (2003) Planning and design for on-road public transport. In: Institute of transport Studies, Eds.

2. Disney J (1998) Competing through quality in transport services. Managing Service Quality 8(2): 112-118.

3. Ahmed S (2004) A study of the performance of bus transport services in some selected routes of Dhaka City, Bangladesh.

4. Hasan MN (1996) The role of double-decker buses as a mode of public transportation in Dhaka City. MURP Thesis, Bangladesh University of Engineering and Technology (BUET), Dhaka, Bangladesh.

5. Firdious GM (1984) A study on the problems of bus transportation in Dhaka City. MURP Thesis, Bangladesh University of Engineering and Technology (BUET), Dhaka, Bangladesh.

6. (2017) Bangladesh - Dhaka Statistical Metropolitan Area.

7. STP (2005) Strategic Transport Plan for Dhaka. Prepared by Louis Berger Group and Bangladesh Consultant Ltd, Bangladesh.

8. Karim MM, Mannan MS (2008) Mass Transit Demand in Dhaka Metropolitan and Review of Alternatives. Ministry of Housing \& Public Works (MHPW).

9. Haque MM (2000) Road Planning and Engineering for Promoting Pedestrian Safety in Bangladesh. 10th REAAA Conference, September, REAAA, Tokyo, Japan.

10. (2015) RSTP interim report.

11. MURP Thesis, Bangladesh University of Engineering and Technology (BUET), Dhaka, Bangladesh.

12. Andaleeb SS, Haq M, Ahmed RI (2007) Reforming inner-city bus transportation in a Developing country: a passenger-driven Model, Journal of Public Transportation 10(1).

13. BRTC (2011) Bangladesh Road Transport Corporation.

14.(2017) Traffic Engineering and Management. Monash: Monash University, Australia.

15. DTCB (2009) Number of buses operating in existing bus routes of Dhaka city. Dhaka Transport Coordination.

16. Haque MM (2000) Road planning and engineering for promoting pedestrian safety in Bangladesh. 


\section{Civil Engineering Research Journal}

(C) This work is licensed under Creative DOI: 10.19080/CERJ.2018.05.555659
Your next submission with Juniper Publishers will reach you the below assets

- Quality Editorial service

- Swift Peer Review

- Reprints availability

- E-prints Service

- Manuscript Podcast for convenient understanding

- Global attainment for your research

- Manuscript accessibility in different formats

( Pdf, E-pub, Full Text, Audio)

- Unceasing customer service

Track the below URL for one-step submission https://juniperpublishers.com/online-submission.php 